\title{
MODERNITY AND BURIAL RITUALS IN IGBO LAND: A PARANORMAL COMMUNICATION APPROACH
}

\author{
Ndukwe Udochukwu Emmanuel ${ }^{1}$, Ihechu Innocent Paschal ${ }^{2}$ \\ and Ralph-Nwachukwu Onyinye ${ }^{3}$ \\ ${ }^{1}$ Department of Mass Communication, Abia State University, PMB 2000, Uturu Nigeria \\ Email: udochukwu.emmanuel@abiastateuniversity.edu.ng; \\ udochukwu2emmanuel@gmail.com; Tel: +2348035725417 \\ ${ }^{2}$ Department of Mass Communication, Abia State University, PMB 2000, Uturu Nigeria \\ Email: ipi@abiastateuniversity.edu.ng; madinopas@ yahoo.com; Tel: +2347065138607 \\ ${ }^{3}$ Department of Mass Communication, Abia State University, Uturu. \\ Email: onyinye.dei2011@gmail.com; Tel: +2348037976002
}

Cite this article:

Ndukwe U.E., Ihechu I.P., Ralph-Nwachukwu O. (2021), Modernity and Burial Rituals in Igbo Land: A Paranormal Communication Approach. British Journal of Mass Communication and Media Research 1(1), 28-38. DOI: 10.52589/BJMCMROXV49EQI.

\section{Manuscript History}

Received: 6 Oct 2021

Accepted: 23 Oct 2021

Published: 14 Nov 2021

Copyright $\odot 2020$ The Author(s). This is an Open Access article distributed under the terms of Creative Commons AttributionNonCommercial-NoDerivatives 4.0 International (CC BY-NC-ND

4.0), which permits anyone to share, use, reproduce and redistribute in any medium, provided the original author and source are credited.
ABSTRACT: The Igbo people believe that a well done burial ritual would determine the well-being of the deceased in the land of the "living-dead". It is therefore expected that their loved ones perform proper burial rituals to ensure the peaceful rest of the deceased and to avert the wrath of the dead. This study examined modernity and burial rituals in Igbo land from a paranormal communication perspective. The Functionalism approach as propounded by Smith, Burner and White in 1956 was used as the theoretical underpinning for this study. This study adopted textual analysis of historical and oral literature. The findings of this study revealed that modernity has affected the Igbo culture, and also showed that there are socio-religious consequences of not meeting up with the burial ritual demands. As a result, the researchers recommend amongst others that stakeholders in the community and the society at large come together to revive the Igbo culture. They also recommend that families do the needful to ensure that their 'dead' is properly buried to avoid certain misfortunes.

KEYWORDS: Extramundane Communication, Burial Rituals, Paranormal Communication, Ethno Communicology, African Communication System. 


\section{INTRODUCTION}

Death is inevitable as every living thing must at some point in life go to rest. In Igbo land, the news of death is often not received with open arms, irrespective of the age of the deceased. Ossai (2016), in his own view, stressed that, irrespective of the age of the deceased, there is always a reason to mourn. Hence, the Igbos are always seen treating the dead with unreserved respect and an uncommon type of complex rituals.

According to Ejizu, as cited in Chinenye (2015), through rituals, man says something about his inner religious awareness, his vision and his belief about the cosmos. Rituals occupy a central position in Igbo traditional religion. The belief of the Igbo people in ancestral existence is the clearest expression of their faith in the afterlife. The same belief is also the dynamic hope of the traditional Igbo - that after a successful career here on earth, one could be happily gathered with his forefathers in the land of the 'living dead', to continue the interminable cycle of life.

While discussing the Igbo culture, Nircle (2015) stated that the Igbo people are known for their unique culture that reflects both in their birth, marriage, death and burial. The news of the 'passing on' of an individual is not just disseminated. According to the Igbo tradition, there is always a laid down procedure for breaking the news of death, especially that of a great man. The first person to be informed is the head of the deceased immediate family (Okpara), he would then inform the entire family, then the head of the extended family (Umunna) is also informed, and finally the head of the village. In some communities, after the village head has been informed, the entire community would be summoned to an "Ikpu oku", the news is usually broken while presenting them with dry gin (Alcohol) and livestock (fowl). After this, the public can then mourn the deceased.

In Igbo land, burials and burial rituals or rites have become a bone of contention and modernity plays a major role in this. Before now, it is believed that before a man or a woman is buried, certain rituals have to be made, such as the "Iwa Nkita Anya", the goat ritual, the cow presentation, mourning, corpse preservation, determining the place for the deceased to be buried, etc. All these rituals have to be performed to ensure that the deceased is properly welcomed by their ancestors. The Igbos believe that a well done burial ritual would determine the well-being of the deceased in the land of his ancestors; some have it that if the burial rituals are not properly done, the spirit of the deceased would roam the earth, causing havoc and destroying lives and properties of their loved ones.

Also, Ihechu and Uchechukwu (2018) asserted that the Igbo people believe that a well done burial ritual would determine the well-being of the deceased in the land of the 'living-dead'. It is often believed that if the burial ritual is not properly done, the dead would be in a state of unrest and cannot partake or mingle with their people in the land of their ancestors. From a mythological viewpoint, Onaja (1988) posits that the dead are viewed as the 'living' that deserves necessary rituals in order to progress to the spirit realm. A closer analysis of his point of view reflects that the spirit of the soul stays with the corpse awaiting burial or funerals. While the soul stays around, the family of the deceased makes plans to bury the dead and also perform the necessary rituals that the soul needs to move ahead, because it is believed that if these rituals are not performed, the dead would keep roaming the street, causing havoc which would finally compel the family to perform all rites to enable the spirit rest from all the troubles. 
In ancient periods, funeral rites in most African communities were colourful and engrossed in ritual practices, but with the arrival of the Christian missionaries in 1843, the ritual practices associated with burials in Igbo land began to change; other Igbo traditional practices such as ancestral worship, widowhood practice and many other practices came under serious attack.

According to Onwuka (2017), the white man's denigration and repudiation of autochthonous cultural systems and practices since his first contact with the Africans in the 15th century, perpetrated with the active connivance of some African stooges, have dealt a huge blow on the wholesomeness of these systems and practices this has whittled down, wittingly or unwittingly, the black man's cultural integrity and pride. The ensuing situation of cultural imperialism and the concomitant inferiority complex on the part of some Africans have continued to receive wide condemnation of perceptive Africans at home and in diaspora.

It would therefore be apt to find out the extent to which modernity, cultural imperialism and Christianity have affected the Igbo funeral rites, as well as explore the consequences of improper burial rituals.

\section{Statement of the Problem}

Modernity has played a big role in effecting change and influencing a lot of things as regards the Igbo funeral rites. Christianity and westernization have also had their toll on the indigenous way of life of the Igbo people. The Igbos are well-known for their rich cultural heritage, and funeral rites and rituals are not an exemption.

Funeral rituals in Igbo land, most especially when it has to do with a married aged person, is usually a colourful celebration, filled with fun, ritual activities and a lot of people because it is regarded as 'good death'. The married aged persons in the Igbo society are usually given a level of respect which is not given to the young and unmarried. For instance, it usually involves the killing of cow and/or horse, goats, dog, hen, etc, depending on the village of the deceased and it is believed that if the rituals are not properly done, the spirit of the deceased would come haunting the family. In the case of the young and unmarried, their spirits, which are often referred to as 'Udi uke', are believed to cause harm upon individuals when they are not properly propitiated. This research work therefore sought to ascertain the socio-religious consequences of not meeting up with the burial rituals demands from a paranormal communication perspective.

\section{Objectives of the Study}

i. To determine the effects of modernity on burial rituals in Igbo land.

ii. To ascertain the socio-religious consequences of not meeting up with the burial rituals demands.

iii. To ascertain the future of burial rituals in Igbo land. 


\title{
Research Questions
}

\author{
i. What are the effects of modernity on burial rituals in Igbo land? \\ ii. What are the socio-religious consequences of not meeting up with the burial rituals \\ demands? \\ iii. What is the future of burial rituals in Igbo land?
}

\section{Theoretical Framework}

Functional approach theory propounded by Smith, Burner and white in 1956 was used as the theoretical underpinning for this research. The functional approach theory holds that ritual behaviour entails an attitude that is concerned with the sacred and sacred act and things; therefore, rituals are nothing more than symbolic representation of society. The theory of functionalism therefore holds that the nature of ritual is to be defined in terms of its function in the society. The aim of this theory is to explain rituals in terms of individual needs and social equilibrium.

According to Salamani (2016), ritual involves a feeling of emotion of respect, awe, fascination or dread in relation to the sacred, with its dependence upon a belief system that is usually expressed in the language of myth and action that is symbolic in relation to its reference.

\section{Research Methodology}

This study employed a textual analysis approach of historical and oral literature. The researcher made use of personal interviews to retrieve the primary data-with a total of four $(\mathrm{N} \sim 4)$ respondents, which includes a traditional religious practitioner, a priest, a scholar and an elderly man. The secondary data were gathered from books, journals, thesis, dissertation and internet materials.

\section{Death and Burial Practice in Igbo land: An Overview}

A number of authors, individuals and even scholars have different perceptions about death and they have also given their different explanations concerning the phenomenon. According to Mbiti (1969), as cited in an Onu and Etefia (2019), death is conceived as a departure and not a complete annihilation of a person. When a man, dies he moves on to join the company of the departed and the only major change is the decay of the physical body, but the spirit moves on to another state of existence; some of the words describing death imply that a person goes 'home' in the hereafter, since one does not depart from there. Mbiti (1969), as cited in Chinenye (2015), also believes that after the physical death, the individual continues to exist in the 'sasa' period and does not immediately disappear from it. At that point, such a person is usually remembered by relatives and friends who knew him in this life and those who have survived him.

Those who survived him call him by name, not necessarily mentioning it; they remember his entire personality, his character, his words and most often the incidents of his lifetime. This is because it is believed that he is not really dead; he is described as being alive. Mbiti describes this group of deceased as 'living dead' and he goes further to explain that the expression 'living- 
dead' refers to a person who has become physically dead but alive in the memory of those who knew him in his lifetime, as well as being alive in the world of the spirits; he is therefore believed to be in the state of personal immortality. Death in Igbo land is therefore not seen as the end of Man; rather, it is seen as the transition from the physical realm to the spirit world (Amaja, 2019).

In Africa, a lot of words are used to describe death. Some refer to dying as being called home or returning home, ceasing to breathe, saying goodbye, answering the summon, joining the fathers, going to sleep or rest. etc. However, other scholars who have done amazing works in the field of burial rituals in Igbo land, such as Ugwu and Uweye (2004), posit that death launches a deadly attack on the society of living men and it not only wrenches but also at the same time dislocates their relationship with one another within the society. Death can therefore be said to be a heartbreaker; those who love the deceased cry, wail and even beat themselves but none of these actions can bring back the dead. The dead are therefore said to have gone to rest in the hereafter. Mbiti (1969) states that death is a monster before which man is utterly helpless. He adds that relatives watch a dying man and cannot assist him to escape death. Most persons who have watched life leave the body of their loved ones describe the experience as unrecoverable. According to one of them, 'he hoped that his scream and tears or even the echo of his voice would bring back his father or maybe a miracle, just anything beyond the natural,' but like Quarcoopome (1982) states, death is a kind of debt to be paid by all.

In Igbo land, most deaths are believed to have been caused by someone or something. As much as there are natural and unnatural causes of death, most Africans don't believe that a man just dies; they always have the belief that it was done by an 'enemy'. Mbiti (1969) is of the opinion that magic, witchcraft and sorcery are the commonest causes of death, and he pointed out that someone is usually blamed for using his magical formula to cause the death of another.

In different parts of Igbo land, there are various manners of approach to burial and burial rites; the concepts have therefore been treated by different authors. Burial is an act of internment of the corpse. Carter (1989) states that burial is the ceremonial internment of a corpse (which probably first occurred in Mousterian times) or a method of disposing of the dead in which the body is placed on a platform above the ground and left to be defleshed by scavengers. In Igbo land, burial and burial rituals/rites take place shortly after death - a little formal process which involves informing the family of the deceased about the death of their loved one, from the immediate family to the entire community before the burial can now be planned. Iwuagu (1979) views burial rituals as an act of worship; he posits that burial rites are seen by the Igbos as an act of worship, propitiating their gods, communicating with the deceased and also as an act of making a thorough appraisal of the success and failures of the deceased in his career on earth.

The Igbos believe that death is not the end of man; they therefore hold their dead in high esteem. They also believe that the dead when properly buried and sent to the land of their progenitors watch over their loved ones in the land of the living. From a mythological viewpoint, Onoja (1988) asserts that when burial is viewed from Igbo mythological perspective, the dead is viewed as a living person that deserves necessary rituals in order to progress to the spirit realm. Looking closely at this perspective, it reflects that the spirit and the soul stay with the corpse awaiting burial or funeral. While the soul stays around, the family makes burial plans to bury the dead and also perform the necessary rituals that the soul needs to move ahead. 
Conclusively, it is worthy of note that burial and burial rites vary from village to village, town to town and so on; so, it would be impossible to give an account of burial rites in the entire Igbo land since they have slight differences.

\section{Burials and Burial Rituals for Different Classes of Individuals in Igbo Land}

Burials and burial rites for different categories of individuals vary in Igbo land. The old and the young are not buried the same way; the rituals differ. The way a title holder is buried and the way an ordinary man is buried differ, etc.

In Igbo land, when a married woman who is aged or with kids dies, the news is not just announced. First, they take the news of her sickness to her maternal relation, and then return in tears to break the news of her death. It is believed that if it is not done this way, the children would be required to pay an amount of money; they need to know the source of her death. After this is done, the maternal relations would break down in tears for their sister and then proceed to ask the children if they intend to bury her immediately. Their response would then determine the next step to take. If their response is 'Yes', members of her maternal home start making preparation to carry her corpse, although this is no longer done as they only carry the corpse symbolically now, but all their rites are provided, some of which include wrapper (ekwa okpe), her drinking pot, basin, kitchen knife and the kitchen seat, etc. An unmarried man is not given respect during his burial. In some places in Igbo land, the corpse is thrown into the evil forest. This is believed to serve as a lesson for other young ones.

Furthermore, when a titled man dies, the corpse is given preferential treatment. They are not permitted to be buried in a communal cemetery; they are buried within the precincts of their own house, with elaborate ceremony. The Ozo title holder is also given a befitting burial, even if the family would have to borrow. Some of the rites that are done for an Ozo title holder include washing the corpse thoroughly with local pomade (elu aki), supervision of the corpse by Ozo titled men to confirm that the body was given due preparation, covering the body with black cloth and placing his cap on his head with eagle feather and a red feather (awo) and his titled staff (arua) put in his hand. In Obimo, the dead Ozo title man's grave is dug into two chambers, one for his corpse and the other for his bed (Onu \& Etefia, 2019). When a child dies, the corpse is thrown into the evil forest. Other factors not mentioned determine how a person would be buried and where such a person would be buried.

\section{Cultural Imperialism at a Glance}

Cultural imperialism is the process and practice of promoting one culture over another. Imperialism destroyed the culture in the entire Igbo land. Imperialism often occurs during colonisation, where a nation overpowers another country and enforces their cultural beliefs on them. Culture can be enforced in various ways, some of which include the laws, movies and magazines all depicting the foreign culture. It is almost safe to say that most of the things we practiced were imbibed from movies, music, the magazines we read, hairstyles, fashion, the way we walk and even the way we talk.

Africa was damaged economically, politically, and culturally. Africa's traditional lifestyle and culture were destroyed. The Europeans had no interest in traditional African culture and had no concern for the Africans. There were several negative effects of colonialism that became evident after many African nations became independent. The Igbo have left their cultural 
heritage to pursue the white man's culture, trying to follow the way they bury their dead, their marriage rites, etc.

\section{The Impact of Christianity and Education on Igbo Burial Rites/Rituals}

There is hardly any aspect of the Igbo culture that education and Christianity has not influenced in one way or another. The history of western education in Nigeria cannot be completed without a reference to the activities of the Wesleyan Methodist Society, Church Missionary Society, the Roman Catholic Holy Ghost Fathers and other societies whose activities led to the effective evangelization of the area that is today called Nigeria (NTI, 2000). The Missionary Societies used the establishment of schools as part of their strategies for the effective and grass-root evangelization of Nigeria. Formal education started with them and ever since then, expansion has continued. Chinenye (2015), advancing the issue further, stated that the missionaries did not waste much time to stop the continued existence of obnoxious cultural practices. For instance, Agha (2004) asserts that these missionaries preached against witchcraft, ritual murder, human sacrifice, killing of twins and their mothers, etc. He states succinctly that "various missionary societies in Nigeria did not leave any stone unturned in their war against the evil cultural practices wherever they existed" (Agha, 2004).

Education is one of the major agents of change in Nigeria as a nation and Igboland specifically, and change is always a constant variable. Some of the obvious changes include the interaction between cultural practices in Igbo land and the pursuit of formal education. A huge amount of money is plunged into the pursuit of formal education to the detriment of a lot of expensive cultural practices.

\section{The Paranormal Communication Question: Do the Gods and Ancestral Spirits Really Come for the Living?}

In Igbo land, not meeting up with the important burial rites comes with grave consequences ranging from unidentifiable sickness, spirit haunting, trouble in business, death of livestock and many more. The living ones are constantly afraid of the malicious activities of the deceased. They are very much alert to satisfy the needs of the deceased so as to ensure that the deceased does not turn back to haunt them and cast their venom on them. The belief that the spirits of the progenitors haunt the abode of the living ones when the latter have not fulfilled or done all the things required of them for their deceased. The belief is so high that almost all are of the view that the progenitors should be accorded their due respect through funeral rites and the presentation and slaughtering of cows or horses on their behalf. There are cases of instant deaths of people who participated financially and very actively in other people's funeral rites prior to similar performance for their deceased father or mother. Cases of such deaths abound but for the interest of privacy, anonymity and for the fact that such deaths lack objective scientific proof, unavoidable rites that must be performed and that a failure to undertake these rites has to go with very serious negative consequences.

\section{The Discourse: The Paranormal Communication Underpinnings in Modernity Vs Igbo Burial Rituals}

\section{RQ 1: What are the effects of modernity on burial rituals in Igbo land?}

Modernity has affected burial rites in Igbo land in no small way. According to Ikechukwu, a priest from Mbano in Imo State, quite a lot has changed when it comes to burial rituals and 
rites; before now when a person dies, most especially if he is an influential person in the society, his corpse is traditionally preserved as there were no mortuaries in those days. The body would be wrapped in clothes and mats and laid on sticks in a small hut and this is usually done in an open room. Fire is made and holes are also made on the sides of the wall so as to allow the smoke to penetrate; it is this smoke that envelops the body and then keeps the body dry for as long as one wants. Other methods were also used in preserving corpses in those days like the herbal concoction and many more. He also stated that in time past, a woman's body is believed not to rest anywhere asides her paternal home, but now, it is no longer the case as the woman as at this time and age is permitted to be buried in her husband's house. The corpse is only taken symbolically and certain ceremonies are done to ensure she rests in peace. Once all the demands made by her maternal home are met, which include the cow, the goat, the hen and the drinks, she can then be buried.

When a married woman who is aged or with kids dies, the news is not just announced. First, they take news of her sickness to her maternal relation; then they return in tears to break the news of her death. It is believed that if it is not done this way, the children would pay 'fine', this is so because they need to know the source of her death. After this is done, the maternal relations would break down in tears for their sister and then proceed to ask the children if they intend to bury her immediately; their response would then determine the next step to take. If their response is 'Yes', members of her maternal home start making preparation to carry her corpse, although this is no longer done as they only carry the corpse symbolically now, but all their rites are provided, some of which include wrapper (ekwa okpe), her drinking pot, basin, kitchen knife and the kitchen seat, etc. An unmarried man is not given respect during his burial in some places in Igbo land; the corpse is thrown into the evil forest. This is believed to serve as a lesson for other young ones.

Onu and Etefia (2019) agreed to this in their research, where they stated that widows no longer go through the rigorous cleansing rituals and all the nightmares that come with it. Modernity has to some extent reduced the health implication, social implication, economic and cultural implication that these rituals have on widows as most learned women will not do it now. The Osu's before now are seen as outcasts and it is believed that their head is not supposed to touch the soil. Before now, the body is hanged with the head halfly cut underneath a pot, so when it decays, it drops into the pot; then the body can be buried. Modernity has changed this; an Osu is now being buried the same way others are buried.

\section{RQ 2: What are the socio-religious consequences of not meeting up with the burial rituals demands?}

Findings from this study also indicate that there are socio-religious consequences of not meeting up with the burial ritual demand. In a personal communication, Ikeokwu, a priest in Isiala-Ngwa South, opened up to us during the interview that truly, there have been cases of men losing their lives when they fail to meet up with the demand and when they provoke the spirit of the deceased. According to him, in cases where a man has not buried his father, satisfying all the necessary demands most especially the goats and the cow ritual, and he goes to another burial where these animals are presented and killed, he must not eat from it. If he does, the spirit of the deceased would haunt him and he would die if something is not done quickly. According to him, this has happened a lot of times even more frequently than he can recall. He gave an example of a man who had not satisfied the ritual demands for his late father but went out to eat the meat of a cow killed for another dead man; according to him, the man 
choked to death. Another man missed his step and fell to his death; there were many other mysterious scenarios. If a man dies and his wife sleeps with another man during her mourning period, she would face grave punishment ranging from ostracism to being sold into slavery and if a child is conceived during the act, the woman might die during childbirth. If the baby survives death, the child is thrown into the evil forest and she is then required to propitiate the gods for desecrating the land.

As proven, the gods really come for those alive if the right things are not done. In Igbo land, not meeting up with the important burial rites comes with grave consequences ranging from unidentifiable sickness, spirit haunting, trouble in business, death of livestock and many more. The belief that the spirits of the progenitors haunt the abode of the living ones when the latter have not fulfilled or done all the things required of them for their deceased is true, although it has not been scientifically proven. The belief is so high that almost all are of the view that the progenitors should be accorded their due respect through funeral rites and the presentation and slaughtering of cows or horses on their behalf.

\section{RQ 3: What is the future of burial rituals in Igbo land?}

Findings from this research show that there is little hope for the Igbos. In a personal interview with Nnanna, an academic, the Igbos want to outdo one another when it comes to burying their dead. They want the burial ceremony to be the talk of the town; they want the entire community to know that they are financially capable enough to do a befitting burial ceremony for their loved one. If this continues this way, there is big hope for the Igbo people. Nnanna stressed his viewpoint by citing the popular Obi Cubana's mother's burial ceremony which took place at Oba, Anambra State, stating how over 200 cows were donated by his committee of friends to ensure that the cow ritual would be properly done. The cow contribution by his Igbo friends alone is an indication of the level of importance placed on the cow ritual, which they are fully aware of.

Moreover, some want to perform all the rituals but they do not want to present the items physically; they just want to pay the cash equivalent and go. They don't want to be involved in buying them because of their religious beliefs and a few other factors. If things continue this way, generations to come may not experience all the colourful rituals performed by those alive to send their dead home in a grand style.

It is important to note that there is hardly any aspect of the Igbo culture that education and Christianity has not influenced in one way or another. The history of western education in Nigeria cannot be completed without a reference to the activities of the Wesleyan Methodist Society, Church Missionary Society, the Roman Catholic Holy Ghost Fathers and other societies whose activities led to the effective evangelization of the area that is today called Nigeria (NTI, 2000). 


\section{CONCLUSION AND RECOMMENDATION}

Modernity has had its toll on the Igbo burial rituals; it is important to note that despite the effect modernity has had on the Igbo burial rituals, there are obvious socio-religious consequences of not laying the deceased to rest, which include unidentifiable sickness, spirit haunting, trouble in business, death of livestock and death in very severe situations. The Igbo people should therefore do the needful to see that their "dead" is properly laid to rest.

The researchers therefore recommend:

i. To preserve burial rites, traditional rulers, priests, scholars and the elderly ones who know this tradition should come together and revive the culture.

ii. Families should do the needful to ensure that their 'dead' is buried properly in order to avoid certain misfortunes.

iii. The Igbo people should be sensitised on the importance of burial rituals and not just see it as a 'ceremony'.

\section{Suggestion for Further Research}

This paper recommends that when other researchers are taking modernity and burial rituals in Igbo land as a research topic, they should also focus on other aspects of it like the effect it has on widows, etc.

\section{REFERENCES}

Agha, U.A. (2004), Christian missionary work \& development in the Nigerian nation, in Okwueze M. I. (Ed.), Religion \& societal development; Contemporary Nigerian perspective. Lagos: Merit International Publishers.

Aneke, E.C.(2011), Socio-religious significance of ritual cow or horse in funeral rites among the people of Nsukka- Sub-cultural area of Igboland, Nigeria. A thesis submitted to the Department of Religion \& Cultural Studies, University of Nigeria, Nsukka, Nigeria.

Carter, V. G. (1989). A dictionary of education. New York: McGraw Hill.

Ejizu, C. (1986), Continuity and discontinuity of Igbo traditional religion, in Metuh, E.I. (Ed.), The Gods in retreat: Continuity and change in African religions. Enugu: Forth Dimension Publishers.

Ihechu, I. P . \& Uchechukwu, L. I. (2018), African communication systems. Enugu: Iyke-Lito Publishers.

Iwuagu, J. N. (1974). Burial rites in Mbaitoli/Ikeduru Local Government Area (B.A. Long Essay). Department of Religion, University Of Nigeria, Nsukka, Nigeria.

Mbiti, J. S. (1969). African religions and philosophy. London: Heinemann Press.

N T I, (2000). NCE/DLS course book on Christian religious studies cycle I. Kaduna: National Teachers Institute.

Onwuka, J.O. (2017), Nigerian societies \& cultural heritage. Owerri: Fasmen Educational And Research Publications.

Quarcoopome, A. N. O. (1987), West African traditional religion. Ibadan: African Universities Press. 
Salmani Nodoushan, M. A. (2016). On the functions of swearing in Persian. Journal of Language Aggression \& Conflict, 4(2), 234-254.

Smith, M. B., Bruner, J. S., \& White, R. W. (1956). Opinions and personality. New York: Wiley.

Solomon-Etefia, P. O. \& Nweya, G. O. (2017). A Pragma-Semiotic analysis of the Catholic bishops communique on the ebola epidemic: Impact on the University of Ibadan Catholic faithful. International Journal of Language Studies, 11(1), 119-142.

Ugwu, C. O. T. \& Ugwueye L. E. (2004), African traditional religion; A Prolegomenon. Lagos: Merit International Publications. 